\title{
Quantitative Constituents Analysis of Rice Mill Wastewater
}

\author{
Motaharul Islam ${ }^{1, a}$, Taslema Nasrin ${ }^{1, b}$, Mosiur Rahman ${ }^{1, c}$, Mofizul Islam ${ }^{1, d, *}$, Tushar Kanti Ray ${ }^{2, e}$ \\ ${ }^{I}$ Department of Agricultural and Industrial Engineering, Faculty of Engineering, Hajee Mohammad Danesh Science and Technology \\ University, Dinajpur-5200, Bangladesh. \\ ${ }^{2}$ Department of Agronomy, Faculty of Agriculture, Hajee Mohammad Danesh Science and Technology University, Dinajpur-5200, \\ Bangladesh. \\ *Corresponding author
}

A R T I C L E I N F O A B S T R A C T

Research Article

In the present world, climate change is a mass talked issue. Because of climate change, humans and animals are under the risk of threatening. The scientist has pointed out that main reasons for climate change are waste. Waste is generated from household chores and industries, factories etc. that are affecting the balance of the environment in many ways. This waste may be of various types such as

Received : 22/10/2019

Accepted : 17/08/2020 solid, liquid, gaseous etc. Therefore, the study was taken to assess the chemical components contain in wastewater in Dinajpur Sadar, Bangladesh. This study was aimed to evaluate the chemical compositions of the generated wastewater including comparison with the groundwater. The data concerning to the rice mill waste water in Dinajpur, Bangladesh was obtained from individual field visits by interviewing with owner and worker in the rice mills. The wastewater samples were collected randomly from different rice mills. A laboratory experiment was performed to determine

Keywords: Wastewater Rice mill Analysis Constituents Comparison the chemical constituents of the wastewater sample. The wastewater contained of $\mathrm{pH}(6.11-6.18)$, EC(181.47-185.23 $\left.\mathrm{MScm}^{-1}\right), \mathrm{Na}\left(26.19-28.89 \mathrm{mgl}^{-1}\right), \mathrm{Ca}\left(45.41-51.26 \mathrm{mgl}^{-1}\right), \mathrm{Mg}\left(47.12-49.8 \mathrm{mgl}^{-}\right.$ $\left.{ }^{1} 0\right), \mathrm{K}\left(184.7-191.3 \mathrm{mgl}^{-1}\right)$, TDS(45.94-47.96 mgl-1), $\mathrm{H}_{\mathrm{T}}\left(306.7-332.33 \mathrm{mgl}^{-1}\right), \mathrm{S}\left(11.05-13.25 \mathrm{mgl}^{-1}\right)$, $\mathrm{Cl}^{-}\left(522.45-526.182 \mathrm{mgl}^{-1}\right), \mathrm{HCO}_{3}^{-}\left(5.12-6.99 \mathrm{mgl}^{-1}\right), \mathrm{DO}\left(0.46-0.53 \mathrm{mgl}^{-1}\right), \mathrm{P}\left(17.01-21.54 \mathrm{mgl}^{-1}\right)$. The obtained concentration of $\mathrm{Ca}, \mathrm{EC}, \mathrm{pH}, \mathrm{Na}$ and $\mathrm{HCO}_{3}^{-}$were within the reported range of groundwater in Dinajpur, Bangladesh. The concentration of $\mathrm{Cl}^{-}, \mathrm{K}, \mathrm{P}, \mathrm{Mg}$ and hardness in the wastewater were above the concentration of reported groundwater in Dinajpur, Bangladesh. On the other hand, the concentration of TDS in the wastewater was less than the reported concentration of groundwater in Dinajpur, Bangladesh.

\footnotetext{
nahidislamae@gmail.com -1mosiurrahman115@gmail.com e tushar.ag.hstu@gmail.com
}

https://orcid.org/0000-0001-9034-4525 https://orcid.org/0000-0002-3797-8390 https://orcid.org/0000-0002-4993-212X

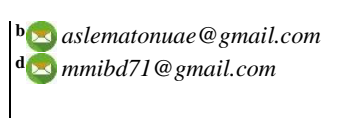

(iD) https://orcid.org/0000-0003-4162-4832
(iD) https://orcid.org/0000-0002-4126-7110

\section{Introduction}

"Waste is an object the holder discards, intends to discard or is required to discard" (European Union., 2008). It is defined as any substances which constitute scraps of materials or other unwanted surplus substances rising from the submission of any process. (EPA., 1990). Waste may be classified mainly into two groups as solid waste and liquid waste. Liquid waste may be defined as the waste mainly composed of uses water and dissolved mud mixed with human and animal excreta, industrial sludge which can be drained out with uses water or for further treatment.

More than 150 rice mills are available in the Dinajpur district in Bangladesh. By the processing of paddy, rice mills discharge huge amount of wastewater and other byproducts. In parboiling process requires huge amounts of water due to soaking. Water-soaked up during the process is about 1.25 times greater than the weight of parboiled paddy. Wastewater is produced at about 1-1.2 L per $\mathrm{kg}$ of paddy processing (Rajesh et al., 1999). Water is the most important factor in the preprocessing of rice after boiling. Wastewater disposal is an important environmental concern. Disposal of wastewater on land is a common practice which results in nutrient overload in soil (Kim et al., 2008) and considerable surface and groundwater quality degradation. Inadequate treatment, followed by discharge into nearby water like as rivers, lakes, and canals with slothful movement can cause eutrophication, odor problems and many other adverse effects (Shrivastava and Soni, 2011). The effluents are generally contained high pollutant, particularly organic materials and nutrients after parboiling process (Santos et al., 2012).

Rice mills are varied widely depending on their capacities. Insure the disposal standards is great importance, 
so the essential treatment is carried out (Mukherjee et al., 2015a). Rice mill wastewater is normally yellowish, pungent odor and consists of organic matter, has a repulsive, and other impurities. When the wastewater released, it contains toxic organic and inorganic contaminants which cause environmental damage. Novel techniques occur for transforming waste products into energy and value-added product. The social, environmental and economic impacts of various industries have led to predictable conflicts between industrial progress and environmental sustainability (Mukherjee et al., 2015a).

The wastewater have negative impacts on biodiversity, due to their mobile nature. Without substantial remediation when they are discharged into natural water bodies, there can be serious, adverse impacts (Alderson et al., 2015). Rice production is a quickly rising industry that plays a leading role in the world economy. Accordingly, rice mill effluents remediation is a serious issue. The management practices of wastewater used in the most rice mills are the disposal of the huge volume of waste by piping or draining system. Sometimes, they use chemicals before disposal for environmental safety but most of the times they are not concerned about environmental safety. They mainly use chemicals for the safety of their boiler and the quality of their rice. Then, they dispose of the wastewater in the side of roads or their pond or in the municipal drain, which leads to a great threat to the environment. It creates an unpleasant odor, seducing the growth of mosquito, reduce water quality, spreading pathogenic micro-organism, some waterborne disease and fill the pond slowly.

For smooth living and better health of human beings, It is very important to increase awareness of the fact that a clean environment is necessary. So this huge amount of liquid waste produces in the rice mills should be managed in a way that it may not hamper the living of human and animal as well as the environment. For this reason, it is important to know the chemical constituents of wastewater for proper management. The study is focused on determining the chemical analysis to know the constituents of rice mill wastewater and its range. Finally, compare it with standard constituents of groundwater of Dinajpur.

\section{Materials and Methods}

\section{Selection of Study Area}

The study was conducted in Sadar Upazila of Dinajpur district in Bangladesh. The area of the Sadar Upazila is $354.34 \mathrm{sq} \mathrm{km}$. The maximum amount of rice is supplied from Dinajpur throughout the country. Also, the number of rice mills are increasing day by day.

\section{Collection of Wastewater Sample}

The sample of wastewater was collected from the different rice mills in the Dinajpur Sadar Upazila in Bangladesh. Three samples were collected randomly from the studied area. The sample was collected in plastic bottles. Samples were brought to the laboratory of the Department of Agricultural Chemistry, HSTU, Bangladesh for testing and samples were analyzed at the laboratory.

\section{An Analytical Method for Analysis of Wastewater}

The major chemical constituents or compounds which are contained in the wastewater are as follows:

\section{Color}

Color in wastewater or water depend on the presence of organic acids, metals, microbiological matter or industrial wastes. At first to determine the color of rice mill wastewater took the sample in a clean conical flux. Then the color of the rice mill wastewater was found the visual inspection of the eye.

Odor

The smell or odor of the wastewater was found when the sample was taken close to the nose. To determine the odor of rice mill wastewater the sample was taken in a clean conical flux then brought the sample close to nose.

\section{Temperature}

Temperature is the measurement of the hotness or coldness of any material. It was measured by the thermometer in the laboratory of the Agricultural Chemistry Department, Hajee Mohammad Danesh Science and Technology University, Dinajpur, Bangladesh.

$p H$

The $\mathrm{pH}$ of wastewater samples was determined electrometrically following by the procedure mentioned by Ghosh et al. (1983) using pH meters (Hanna instrument211 model) in the laboratory of Agricultural Chemistry Department, Hajee Mohammad Danesh Science and Technology University, Dinajpur, Bangladesh.

\section{Electrical conductivity (EC)}

The electrical conductivity of a system represents the concentration of total dissolved solids (TDS) or total salinity in water excluding the amount of silica. The EC of collected water samples were determined by Conductivity Bridge (Harnainstrument-HI8033) as outlined by Ghosh et al. (1983) in the laboratory of the Agricultural Chemistry Department, Hajee Mohammad Danesh Science and Technology University, Dinajpur, Bangladesh.

Total dissolved solids (TDS)

Total dissolved solids are the term used to describe the small amount of organic matter and the inorganic salt present in solution in water. Total dissolved solids (TDS) was obtained by weighing the solid residue obtained by evaporating a measured aliquot of filtered water samples to dryness, according to the procedure described by Chopra and Kanwar (1980).

Calcium ( $\mathrm{Ca})$

At first, it took exactly $40 \mathrm{ml}$ wastewater sample in a $250 \mathrm{ml}$ conical flask. Then, $50 \mathrm{ml}$ of hot distilled water and $5 \mathrm{ml} \mathrm{NaOH}$ (10\%) were added into solution. After that, the flask was shaked thoroughly. 10 drops each of Hydroxylamine hydrogen chloride, Potassium ferrocyanide, Triethanolamine were added the flask. Then, 4-5 drops of falcon indicator solution were added the flask and shaked. The solution was titrated against $\mathrm{Na}_{2}$-EDTA of $0.01 \mathrm{M}$ from a burette to the conical flux. Experiment were repeated the at least 3 times for better result. Blank experiment was conducted taking all the reagents except wastewater. The data was tabulated and calculated from the supplied wastewater.

\section{Magnesium $(\mathrm{Mg})$}

At first, exactly $40 \mathrm{ml}$ wastewater sample was taken into a $250 \mathrm{ml}$ conical flask. Then, $50 \mathrm{ml}$ hot distilled water and $5 \mathrm{ml} \mathrm{NH}_{3}-\mathrm{NH}_{4}$ buffer solution were added. Shake the flask thoroughly. After that 10 drops each of Sodium tungstate solution, Hydroxylamine hydrogen chloride, Potassium ferrocyanide, Triethanolamine were added and 
the flask was shaked thoroughly. Then, 4-5 drops of EBT indicator solution were added and the flask was shaked thoroughly. Titrated the solution against $\mathrm{Na}_{2}$-EDTA $(0.01 \mathrm{M})$ from a burette to conical flux. The experiment were added at least 3 times. Blank experiment were conducted taking all the reagents except irrigation water. Tabulated the data and calculated the amount of calcium from the supplied sample.

\section{Sodium ( $\mathrm{Na}$ ) and Potassium (K)}

Amount of Sodium and Potassium were determined with the help of Flame emission Spectrophotometer using sodium and potassium filter respectively. The sample was aspirated into a gas flame and excitation was carried out in carefully controlled and reproducible conditions. The air pressure was fixed at $10 \mathrm{psi}$. The desired spectral line was isolated using interference filters. The intensity of light at $589 \mathrm{~nm}$ and 768 $\mathrm{nm}$ is approximately proportional to the concentration of the elements sodium and potassium, respectively. The percent emission was recorded according to the methods outlined by Golterman (1971) and Ghosh et al. (1983).

\section{Phosphorus $(P)$}

Firstly, exactly $5 \mathrm{ml}$ water sample was taken in a 100 $\mathrm{ml}$ volumetric flask and $4 \mathrm{ml}$ of sulphomolybdic acid solution was added. It followed by the addition of distilled water up to $2 / 3$ rd volume of the flask. Secondly, the solution were mixed thoroughly after the addition of 5-6 drops of stannous chloride solution. Then, the volume of solution was made up to the mark with distilled water. Developed the full-color intensity within 3-4 minutes and then read the colored solution instantly in a spectrophotometer at $660 \mathrm{~nm}$ wavelength. After that blank solution were prepared by taking all the reagents as described except phosphorus solution. Standard or calibration curve were prepared by plotting the absorbance (optical density) of light in the $\mathrm{Y}$-axis and concentrations of the solutions in $\mathrm{X}$-axis in a graph paper. By plotting the spectrophotometer reading on the standard curve, the concentration of the test sample was easily obtained.

\section{Sulfur $(S)$}

At the beginning dissolved $0.769 \mathrm{~g}$ of Epsom salt $\left(\mathrm{MgSO}_{4} .7 \mathrm{H}_{2} \mathrm{O}\right)$ in a $1000 \mathrm{ml}$ volumetric flask to was made a standard solution of 100 ppm sulfur. Then from the 100 ppm solution, a standard series sulfur solution was prepared and added about $0.3 \mathrm{~g}$ (1 scoop) barium chloride to each standard series. After that about $0.3 \mathrm{~g}$ (1 scoop) barium chloride was added to $20 \mathrm{ml}$ of the unknown test solution. It was mixed until barium chloride dissolves completely and allowed to stand it for 30 minutes before reading. Took spectrophotometer reading at $425 \mathrm{~nm}$ wavelength putting the cuvette in the cuvette chamber against the blank one. Then found out the concentration of sulfate from the standard curve.

\section{Hardness $\left(H_{T}\right)$}

It largely depends on the amount of calcium and magnesium in the water. After determining the amount of calcium and magnesium, the hardness of the water was determined by the below equation:

$$
\mathrm{H}_{\mathrm{T}}=\left(2.5 \times \mathrm{Ca}^{2+}\right)+\left(4.1 \times \mathrm{Mg}^{2+}\right) .
$$

\section{Chloride $\left(\mathrm{Cl}^{-}\right)$}

Firstly, $3.4 \mathrm{~g}$ of $\mathrm{AgNO}_{3}$ were taken in a $1000 \mathrm{ml}$ volumetric flask and $200-300 \mathrm{ml}$ distilled water was added and then mixed it to dissolve properly and added distilled water to make up the volume. Secondly, $1.2 \mathrm{~g} \mathrm{k}_{2} \mathrm{CrO}_{4}$ were taken into $250 \mathrm{ml}$ volumetric flux and 100-150 ml distilled water and 1-2 drops saturated $\mathrm{AgNO}_{3}$ solution were added to made volume up to the mark adding distilled water. Then $5 \mathrm{ml}$ of sample was taken in a $250 \mathrm{ml}$ conical flask and 20 $\mathrm{ml}$ distilled water added and 5-6 drops $\mathrm{k}_{2} \mathrm{CrO}_{4}$ added then titrated against $0.02 \mathrm{~N} \mathrm{AgNO}_{3}$ solution until red brick tinge appeared or brick red precipitation. $1 \mathrm{ml} 1 \mathrm{~N} \mathrm{AgNO}_{3}$ solution equivalent $0.03546 \mathrm{~g} \mathrm{Cl}^{-}$

\section{Bicarbonate $\left(\mathrm{HCO}_{3}^{-}\right)$}

Bicarbonate of wastewater samples was determined by the acidimetric method of titration using phenolphthalein indicator $\left(\mathrm{C}_{2} \mathrm{OH}_{14} \mathrm{O}_{4}\right)$ for carbonate, with diluted sulphuric acid, bicarbonate forms rose-red color complex at the end of titration. The bicarbonate was estimated titrimetric ally after Chopra and Kanwar (1980) and Ghose et al. (1983).

\section{Dissolved oxygen (DO)}

Dissolved oxygen denotes to the level of free, noncompound oxygen present in water or other liquid. It was measured by DO meter (DO-5509) in the laboratory of the Agricultural Chemistry Department, Hajee Mohammad Danesh Science and Technology University, Dinajpur, Bangladesh.

\section{Results and Discussion}

\section{The Present Situation of the Study Area}

The waste generated from the rice mill was in solid and liquid state. Solid waste is including rice husk, chaff, bran and liquid waste is including wastewater. Husk was used for power generation purposes and also used for cow fodder. But, wastewater was not used for any purpose. The source of wastewater was soaking, parboiling, milling of the paddy. It depends on the characteristics of paddy, milling capacity, milling quality and consumer demand. The paddy was parboiled per day varied from 10 to 150 tons in studied rice mills. The wastewater produced varied from 0.0625 to 2.5 $1 / \mathrm{kg}$. The mean wastewater produced is $0.6051 / \mathrm{kg}$. It depends on the amount of paddy processing per day and the amount of water needed for processing. Also, depend on the characteristics of the paddy. There wastewater had no effect upon the health of the labor. But sometimes the labor to do the work comfortably because of odor problems when used open drainage system. In some rice mills, labors used a mask during working in the mill. Workers used a mask for the safety of their health. But most of the workers in the mills did not use the mask. The factor of the wastewater generation depends on the type of paddy, moisture content of paddy, the amount of paddy, the capacity of the boiler. The wastewater was not reused in the studied rice mills. It was considered if the water reused for parboiling of rice, the quality of the milled rice will be hampered. For this reason, the wastewater was not reused and disposed of through a pipe or drain to the pond or canal. Treatment is needed for the reuse of wastewater. It requires a high amount of investment which increases the production cost and needs extra time. So the reuse of wastewater was not effective.

\section{Disposal System}

The disposal system used on studied rice mills either drainage system or piping system. Most of the rice mill used a drainage system and some were used piping systems 
for disposal of wastewater. It is an easy and cost-effective method for disposal of wastewater. It is a permanent system made by concrete when used drainage system and used PVC pipe for piping system. Finally, the wastewater was disposed of in the fallow land, pond, river, municipal drainage, along with road site and the open land. There was no concerned about where the wastewater finally disposed. No chemical was used during disposal. Some of the rice millers used chemicals during the parboiling process but not during disposed of wastewater. Hydrox and added gas tablet in the boiler were used as chemical. Those chemicals were used for keeping the water container in better condition and produced the better quality of rice.

\section{Effect on Environment}

As the wastewater disposed of in the field, fallow land, road site, pond, river, and the municipal drain, so it is a serious environmental concern. When the wastewater disposed of in the roadside, pond, it created bad odor it seems to be very unhygienic. The wastewater decreased the quality of soil and the quality of water. The wastewater was also harmful for the pisciculture, aquatic plants and waterborn animals (Alderson et al., 2015)

Color

The color of rice mill wastewater was brown and turbid. The turbidity was found due to the size, shape, colored compounds and refractive index of the particulate impurities like finely divided organic and inorganic matter present in the water sample. It changed the color, retard the penetration of sunlight with decreased in photosynthetic activity and reduction of oxygen content and made the water inappropriate for use.

\section{Odor}

The odor of the rice mill wastewater was found foul or unpleasant. The offensive odor might be due to the presence of volatile substance associated with organic matter and anaerobic decomposition by living organisms, mainly microorganisms. The offensive odor spoils water quality and causes nausea and vomiting.

\section{Temperature}

Temperature is the measurement of the hotness of any material. The water temperature measurement is important basically for its effects on the biochemical reactions in the living organisms. Another importance temperature is the determination of conductivity, $\mathrm{pH}$ and saturation level of gases in water. In the studied samples, the temperature was ranged from $30.7^{\circ} \mathrm{C}$ to $30.9^{\circ} \mathrm{C}$ (November).

$$
p H
$$

The value of the $\mathrm{pH}$ of the studied samples was ranged from 6.11 to 6.18 . The $\mathrm{pH}$ is the determination of concentration of hydrogen ion. It also indicates quickly the intensity of alkalinity in water or effluent. It affects many biological systems and chemical reactions function only in narrow $\mathrm{pH}$ ranges. The concentration of hydrogen ion in water have influenced the dissociation of water and also the relationship between the concentration of carbonic acid $\left(\mathrm{HCO}_{3}{ }^{-}\right)$and its ions $\left(\mathrm{H}^{+}, \mathrm{CO}_{2}^{3}\right)$ as well as by the generation of these ions from the humic acids and by the hydrolysis of heavy metal salts. From the $\mathrm{pH}$ value of the studied sample, it was found that the sample was slightly acidic. The tolerance limit of $\mathrm{pH}$ of ISI within (5.5 to 9.0) recommended for the discharge of industrial wastewater on land for irrigation as well as into domestic surface water.
The $\mathrm{pH}$ of groundwater collected from Dinajpur district, Bangladesh varied from 5.32 to 7.00 (Uddin, 2004).

\section{Electrical Conductivity (EC)}

Electrical conductivity is the determination of a solution or substance is the capacity to conduct electricity. The concentrations of various ionic particles in water have appeared through this parameter. The electrical conductivity of studied samples were found from 181.47 $\mu \mathrm{Scm}^{-1}$ to $185.23 \mu \mathrm{Scm}^{-1}$. The electrical conductivity in Dinajpur district in Bangladesh groundwater ranged from 75.47 to $565.35 \mu \mathrm{Scm}^{-1}$ (Uddin, 2004).

\section{Total Dissolved Solids (TDS)}

The total dissolved solids are known as the soluble compound (both organic and inorganic) present in the effluent or wastewater. The amount of total dissolved solids in studied samples were found $45.94 \mathrm{mgl}^{-1}$ to 47.96 $\mathrm{mgl}^{-1}$. The mean value of the total dissolved solid was 46.7 $\mathrm{mgl}^{-1}$. For the discharge of the industrial effluent on to land or into inland water, the value of dissolved solids in the wastewater was within the prescribed tolerance limit of ISI $\left(100 \mathrm{mgl}^{-1}\right)$. The reported concentration of TDS of groundwater in Dinajpur district, Bangladesh ranged from 52.02 to $422.51 \mathrm{mgl}^{-1}$ (Uddin, 2004).

\section{Calcium $(\mathrm{Ca})$}

The concentration of calcium was found in studied samples were ranged from $45.41 \mathrm{mgl}^{-1}$ to $51.26 \mathrm{mgl}^{-1}$. The mean value of the calcium in the sample was $48.09 \mathrm{mgl}^{-1}$. The concentration of calcium content in water largely depends on the solubility of $\mathrm{CaCO}_{3}, \mathrm{CaSO}_{4}$, and rarely on $\mathrm{CaCl}_{2}$ (Karanth, 1994). Uddin, (2004) reported that the concentration of calcium in Dinajpur district, Bangladesh groundwater ranged from 4.21 to $72.54 \mathrm{mgl}^{-1}$.

\section{Magnesium $(\mathrm{Mg})$}

The minimum concentration of $\mathrm{Mg}$ was found in studied samples were $47.12 \mathrm{mgl}^{-1}$ and maximum of $49.80 \mathrm{mgl}^{-1}$. The mean value of the $\mathrm{Mg}$ in the sample was $48.61 \mathrm{mgl}^{-1}$. The concentration of $\mathrm{Mg}$ in Dinajpur district, Bangladesh groundwater ranged from 0.85 to $18.60 \mathrm{mgl}^{-1}$. (Uddin, 2004). It was found that the magnesium content is higher than the groundwater reported in Dinajpur district, Bangladesh.

\section{Sodium $(\mathrm{Na})$}

Sodium is one of the most important cations present in water. It is highly soluble in water. The sodium related to chloride and sulfate which creates the water unportable. The high sodium contain water is not suitable for agriculture because it tends to deteriorate the soil for crops. In studied samples, the sodium content of rice mill wastewater was a minimum of $26.19 \mathrm{mgl}^{-1}$ and a maximum of $28.89 \mathrm{mgl}^{-1}$ as mentioned in Table 1 . The mean value was $27.5 \mathrm{mgl}^{-1}$. The amount of sodium in Dinajpur district, Bangladesh groundwater ranged from 2.29 to $54.02 \mathrm{mgl}^{-1}$ reported by Uddin (2004).

\section{Potassium (K)}

Potassium is a naturally occurring element like sodium and remains in solution without undertaking any precipitation. In studied samples, the potassium content ranged from $184.7 \mathrm{mgl}^{-1}$ to $191.3 \mathrm{mgl}^{-1}$. The mean value of potassium in the wastewater sample was $187.5 \mathrm{mgl}^{-1}$ shown in Table 1. The concentration of potassium in groundwater of Dinajpur district in Bangladesh ranged from 0.39 to $57.08 \mathrm{mgl}^{-1}$ (Uddin, 2004). The concentration of potassium in studied samples above the reported range of groundwater in the Dinajpur district in Bangladesh. 
Table 1. Amount of different components of studied samples

\begin{tabular}{l|cccccc}
\hline \multicolumn{1}{c}{ Components } & $\begin{array}{c}1^{\text {st }} \text { Sample } \\
\left(\mathrm{mgl}^{-1}\right)\end{array}$ & $\begin{array}{c}2^{\text {nd }} \text { sample } \\
\left(\mathrm{mgl}^{-1}\right)\end{array}$ & $\begin{array}{c}3^{\text {rd }} \text { sample } \\
\left(\mathrm{mgl}^{-1}\right)\end{array}$ & $\begin{array}{c}\text { minimum value } \\
\left(\mathrm{mgl}^{-1}\right)\end{array}$ & $\begin{array}{c}\text { maximum value } \\
\left(\mathrm{mgl}^{-1}\right)\end{array}$ & $\begin{array}{c}\text { mean value } \\
\left(\mathrm{mgl}^{-1}\right)\end{array}$ \\
\hline $\mathrm{pH}($ no unit $)$ & 6.11 & 6.18 & 6.13 & 6.11 & 6.18 & 6.14 \\
$\mathrm{HCO}_{3}^{-}$ & 5.89 & 5.12 & 6.99 & 5.12 & 6.99 & 6.0 \\
$\mathrm{~K}$ & 191.3 & 184.7 & 186.5 & 184.7 & 191.3 & 187.5 \\
$\mathrm{Na}$ & 27.39 & 28.89 & 26.19 & 26.19 & 28.89 & 27.5 \\
$\mathrm{P}$ & 17.77 & 17.01 & 21.54 & 17.01 & 21.54 & 18.77 \\
$\mathrm{~S}$ & 11.05 & 12.37 & 13.25 & 11.05 & 13.25 & 12.22 \\
$\mathrm{Hardness} \mathrm{H}_{\mathrm{T}}$ & 332.33 & 306.71 & 319.55 & 306.71 & 332.33 & 319.53 \\
$\mathrm{Cl}$ & 525.81 & 522.45 & 526.18 & 522.45 & 526.18 & 524.81 \\
$\mathrm{TDS}$ & 46.21 & 45.94 & 47.96 & 45.94 & 47.96 & 46.7 \\
$\mathrm{EC}\left(\mu \mathrm{scm}^{-1}\right)$ & 185.23 & 182.79 & 181.47 & 181.47 & 185.2 & 183.2 \\
$\mathrm{DO}$ & 0.46 & 0.51 & 0.53 & 0.46 & 0.53 & 0.5 \\
$\mathrm{Mg}$ & 49.80 & 47.12 & 48.91 & 47.12 & 49.80 & 48.61 \\
$\mathrm{Ca}$ & 51.26 & 45.41 & 47.61 & 45.41 & 51.26 & 48.09 \\
Temperature $\left({ }^{\circ} \mathrm{C}\right)$ & 30.7 & 30.9 & 30.8 & 30.7 & 30.9 & 30.8 \\
\hline
\end{tabular}

Table 2. Comparison of different components of studied waste water with the ground water

\begin{tabular}{l|ccc}
\hline \multicolumn{1}{c|}{ Components } & Range of waste water $\left(\mathrm{mgl}^{-1}\right)$ & Range of ground water in Dinajpur $\left(\mathrm{mgl}^{-1}\right)$ & References \\
\hline $\mathrm{Cl}^{-}$ & 524.81 & $5.67-63.46$ & Uddin, 2004. \\
$\mathrm{HCO}_{3}{ }^{-}$ & 6.0 & $2-6.20$ & Hossain, 2014. \\
$\mathrm{K}$ & 187.5 & $0.39-57.08$ & Uddin, 2004. \\
$\mathrm{Na}$ & 27.5 & $2.29-54.02$ & Uddin, 2004. \\
$\mathrm{P}$ & 18.77 & $0.001-1.08$ & Hossain, 2014. \\
$\mathrm{~S}$ & 12.22 & - & - \\
$\mathrm{H}_{\mathrm{T}}$ & 319.52 & $14.01-242.19$ & Uddin, 2004. \\
$\mathrm{P}^{\mathrm{H}}($ no unit $)$ & 6.14 & $5.32-7.00$ & Uddin, 2004. \\
$\mathrm{TDS}$ & 46.7 & $52.02-422.51$ & Uddin, 2004. \\
$\mathrm{EC}\left(\mu \mathrm{scm}^{-1}\right)$ & 183.2 & $75.47-565.35$ & Uddin, 2004. \\
$\mathrm{Mg}$ & 48.61 & $0.85-18.60$ & Uddin, 2004. \\
$\mathrm{Ca}$ & 48.09 & $4.21-72.54$ & Uddin, 2004. \\
$\mathrm{DO}$ & 0.5 & - & - \\
\hline
\end{tabular}

\section{Phosphorus (P)}

The phosphorus content in studied samples was found within the range from $17.01 \mathrm{mgl}^{-1}$ to $21.54 \mathrm{mgl}^{-1}$. The mean value of phosphorus in the studied sample was $18.77 \mathrm{mgl}^{-1}$. The reported amount of phosphorus in Dinajpur district, Bangladesh groundwater ranged from 0.001 to $1.08 \mathrm{mgl}^{-1}$ (Hossain, 2014), as shown in Table 2. The concentration of phosphorus in the studied sample above the reported range of groundwater in Dinajpur district in Bangladesh.

\section{Sulfur (S)}

The minimum amount of sulfur content in studied wastewater was obtained $11.05 \mathrm{mgl}^{-1}$ and a maximum of $13.25 \mathrm{mgl}^{-1}$. The gained mean value of sulfur in studied samples was $12.22 \mathrm{mgl}^{-1}$.

\section{Hardness $\left(H_{T}\right)$}

To assess the quality of water hardness is an important parameter, when it is to be used for domestic, agricultural and industrial purposes. Principal cations conveying hardness are calcium and magnesium and other cations are iron, manganese, aluminum, barium, and strontium. The anions responsible for hardness are mainly bicarbonate, carbonate, sulfate, and chloride, etc. Hardness is temporary if it is instigated by carbonate and bicarbonate salts of the cation. Sulfate and chloride are responsible for the permanent hardness of the metals. The minimum amount of hardness in studied samples was found $315.34 \mathrm{mgl}^{-1}$ and a maximum of $322.03 \mathrm{mgl}^{-1}$ represents in Table 1 . The mean value was $319.52 \mathrm{mgl}^{-1}$. The concentration of hardness in groundwater of Dinajpur district, Bangladesh ranged from 14.01-242.19 $\mathrm{mgl}^{-1}$. (Uddin, 2004). The concentration of $\mathrm{H}_{T}$ in the studied sample above the reported range of groundwater in the Dinajpur district, Bangladesh.

\section{Chloride $\left(\mathrm{Cl}^{-}\right)$}

Chloride is found in all types of water. In natural freshwater chloride concentrations is fairly low and normally less than that of sulfate. When discharge of industrial effluent and domestic sewage in water, the concentrations of chloride tend to increase. The amount of chloride in the studied rice mills wastewater was found in the range from $522.45 \mathrm{mgl}^{-1}$ to $526.182 \mathrm{mgl}^{-1}$ as presented in Table 1. The mean value of chloride was $524.81 \mathrm{mgl}^{-1}$. The concentration of chloride in Dinajpur district, Bangladesh groundwater ranged from 5.67 to $63.46 \mathrm{mgl}^{-1}$ (Uddin, 2004) shown in Table 2.

\section{Bicarbonate $\left(\mathrm{HCO}_{3}^{-}\right)$}

The minimum amount of bicarbonate in studied samples was $5.12 \mathrm{mgl}^{-1}$ and a maximum of $6.99 \mathrm{mgl}^{-1}$. The mean value of bicarbonate was $6.0 \mathrm{mgl}^{-1}$. The range of $\mathrm{HCO}_{3}{ }^{-}$in Dinajpur groundwater was 2 to $6.20 \mathrm{mgl}^{-1}$ (Hossain, 2014). The amount of $\mathrm{HCO}_{3}^{-}$in the studied sample within the range of groundwater in the Dinajpur district in Bangladesh. 


\section{Dissolved Oxygen (DO)}

Dissolved oxygen is one of the most important parameter to assess the quality of water for various purposes. DO concentration indicates the ability to support aquatic life in water. In clean surface water DO is started about $7.6 \mathrm{mgl}^{-1}$ at $30^{\circ} \mathrm{C}$. Inorganic reductants like as hydrogen sulfide, nitrite, ammonia, ferrous ion and other oxidizable substances also tend to decrease DO content in water. In studied samples, the DO content was ranged from $0.46 \mathrm{mgl}^{-1}$ to $0.53 \mathrm{mgl}^{-1}$. The mean value was $0.5 \mathrm{mgl}^{-1}$.

The amount of different components of studied samples are shown in Table 1. The comparison of different components of studied samples with ground water in Dinajpur district in Bangladesh are shown in Table 2.

After the chemical analysis, it was found that the concentration of $\mathrm{Ca}, \mathrm{EC}, \mathrm{Na}, \mathrm{HCO}_{3}^{-}$, and $\mathrm{pH}$ in the wastewater within the ranged of groundwater in Dinajpur, Bangladesh reported by Uddin (2004). But the concentration of $\mathrm{Cl}^{-}, \mathrm{K}, \mathrm{P}, \mathrm{Mg}$ and hardness in the wastewater were above the concentration of reported groundwater in Dinajpur, Bangladesh. But on the other hand, the amount of TDS in the wastewater was less than the concentration of groundwater in Dinajpur, Bangladesh.

The treatment of the wastewater is required to render the suitablity for discharge into inland surface waters. Further, the appropriateness of the wastewater for agricultural use may be tried and if required appropriate treatment can be made to render the wastewater suitable for irrigation.

\section{Summary and Conclusion}

During the investigation, it was found that the wastewater in the rice mills is generated for the parboiling of rice. The generated wastewater was disposed of either by drainage system or by the piping system to open lake, municipal drain, to the pond, river or roadside land. For those unplanned dispose of wastewater creates bad odor, environmental pollution, decreases the quality of water, decreases the quality of soil and health hazard. The safe discharge of wastewater is necessary if rice mills are to meet the increasingly stringent regulations of law, health and environment sustainability.

In the studied sample it was observed that the concentration of $\mathrm{pH}$ in different samples ranged from 6.11 to 6.18 , which is slightly acidic. The concentration of EC ranged from 181.47 to $185.23 \mu \mathrm{scm}^{-1}$, TDS ranged from 45.94 to $47.96 \mathrm{mgl}^{-1}$, Ca ranged from 45.41 to $51.26 \mathrm{mgl}^{-1}$, $\mathrm{Na}$ ranged from 26.19 to $28.89 \mathrm{mgl}^{-1}, \mathrm{~K}_{\text {ranged from } 184.7}$ to $191.3 \mathrm{mgl}^{-1}$, $\mathrm{P}$ ranged from 17.01 to $21.54 \mathrm{mgl}^{-1}, \mathrm{~S}$ ranged from 11.05 to $13.25 \mathrm{mgl}^{-1}$, Hardness ranged from 306.7 to $332.33 \mathrm{mgl}^{-1}, \mathrm{Mg}$ ranged from 47.12 to $49.80 \mathrm{mgl}^{-1}, \mathrm{Cl}^{-}$ ranged from 522.45 to $526.182 \mathrm{mgl}^{-1}, \mathrm{HCO}_{3}{ }^{-}$ranged from 5.12 to $6.99 \mathrm{mgl}^{-1}$, DO ranged from 0.46 to $0.53 \mathrm{mgl}^{-1}$. The concentration of $\mathrm{Ca}, \mathrm{EC}, \mathrm{Na}, \mathrm{HCO}_{3}{ }^{-}$, and $\mathrm{pH}$ in the wastewater within the range of groundwater in Dinajpur, Bangladesh. But the concentration of $\mathrm{Cl}^{-}, \mathrm{K}, \mathrm{P}, \mathrm{Mg}$ and hardness in the wastewater are above the concentration of groundwater in Dinajpur, Bangladesh. But on the other hand, the concentration of TDS in the wastewater are less than the concentration of groundwater in Dinajpur, Bangladesh which is abnormal for soil and environment. So the waste water management personnel should be trained by experts. The overall waste management process and disposal system should be regularly monitoring by concern authority.

\section{References}

Alderson MP, Santos ABD, Filho CRM. 2015. Reliability analysis of low-cost, full-scale domestic wastewater treatment plants for reuse in aquaculture and agriculture. Ecol.Eng.,82:6-14.

Chopra SL, Kanwar JS. 1980. Analytical Agricultural Chemistry. Kalyani Publishers. Ludhiana, New Delhi, pp, 148-289.

EPA. 1990. Recommended buffer distance for industrial residual air emissions. Environment Protection Authority of Victoria, Publication No. AQ 2186. Melbourne, Australia.

European Union. 2008. The waste framework directive. Art. 3(1). Golterman HL, Clymo RS. 1971. Methods for Chemical Analysis of Fresh Waters. IBP Handbook No. 8. Blackwell Scientific Publications. Oxford and Edenbourgh., 41-46.

Gosh AB, Bajaj JC, Hasan R, Sing D. 1983. Soil and Water Testing Method. A Laboratory Manual, Division of Soil Science and Agricultural Chemistry. IARI. New Delhi1100012., 1-48.

Hossain MA. 2014. Chemical constituents and suitability studies of ground water for irrigation uses in Dinajpur. M.S. Thesis, Department of Agricultural Chemistry, Hajee Mohammad Danesh Science and Technology University, Dinajpur.

Karanth KR. 1994. Groundwater Assessment Development and Management. TATA McGraw-Hill Publishing Company Limited. New Delhi,pp, 217-273.

Kim SM, Im SJ, Park SW, Lee JJ, Benham BL, Jang TI. 2008. Assessment of wastewater reuse effects on nutrient loads from paddy field using field-scale water quality model. Environ. Model Assess., 13: 305 -313.

Mukherjee B, Majumdar M, Gangopadhay A, Chakraborty S, Chaterjee D. 2015a.Phytoremediation of parboiled rice mill wastewater using water lettuce (Pistiastratiotes). Int. J. Phytorem., 17:651-656.

Rajesh G, Bandyopadhyay M, Das D. 1999. Some studies on UASB bioreactor for the stabilization of low strength industrial effluents. Bioprocess Eng., 21: 113 -116.

Santos DGDL, Turnes CG, Conceicao FR. 2012. Bioremediation of parboiled rice effluent supplemented with biodieselderived glycerol using PichiapastorisX-33.Sci.WorldJ.

Shrivastava PV, Soni SB. 2011. Treatment of rice mill effluent for pollution control by electrocoagulation. J. Chem. Biol. Phys. Sci., 2:480 -483.

Uddin MG. 2004. Comparative studies of ground water quality at different aquifers of Dinajpur district. M.S. Thesis, Department of Agricultural Chemistry, Bangladesh Agricultural University, Mymensingh. 